\title{
Cold Hardiness of Grevillea in Western Oregon
}

\author{
Neil Bell ${ }^{1}$, Heather Stoven ${ }^{2}$, James S. Owen Jr. ${ }^{3}$, \\ and James E. Altland ${ }^{4}$
}

AdDitional Index wORDs. landscape, ornamental plant, Pacific Northwest, shrub, spider flower, temperature

Summary. A cold hardiness evaluation of 57 cultivars and species of grevillea (Grevillea) was conducted from 2011 to 2014 in Aurora, OR, to assess landscape suitability in the Pacific Northwest United States. Plants were established using irrigation in 2011 , but they received no supplemental water, mineral nutrients, or pruning from 2012 to 2014. Plants were evaluated for injury in Mar. 2012 and Jan. 2014 after winter cold events with minimum temperatures of -4 and $-13{ }^{\circ} \mathrm{C}$, respectively. Damage, at least on some level, occurred on most selections following their first winter after planting in 2011. During Winter 2013, further damage to, or death of, 33 grevillea cultivars or species occurred. The grevillea that exhibited the least cold damage and the most promise for landscape use and further evaluation in the Pacific Northwest United States were 'Poorinda Elegance' hybrid grevillea, southern grevillea ( $G$. australis), cultivars of juniper-leaf grevillea ( $G$. juniperina) including Lava Cascade and Molonglo, and oval-leaf grevillea (G. miqueliana), all of which exhibited minor foliage damage.

G revillea is a genus of evergreen shrubs in the family Proteaceae. Currently, 362 species are recognized, almost all of which are found in Australia; only a few are found in New Guinea, New Caledonia, and Sulaweisi (Makinson, 2000). Grevillea commonly grow in sclerophyll forests and heaths, with fewer occurring in rainforest or desert environments

Received for publication 17 May 2019. Accepted for publication 8 Oct. 2019

Published online 20 November 2019.

${ }^{1}$ Oregon State University Extension Service, Marion County, 1320 Capitol Street NE Suite 110, Salem, OR 97301

${ }^{2}$ Oregon State University Extension Service, Yamhill County, 2050 NE Lafayette Avenue, McMinnville, OR 97128

${ }^{3}$ Virginia Polytechnic Institute and State University, School of Plant and Environmental Sciences, Hampton Roads Agricultural Research and Extension Center, 1444 Diamond Springs Road, Virginia Beach, VA 23455

${ }^{4}$ Research Horticulturist, Application Technology Research Unit, U.S. Department of AgricultureAgricultural Research Service, Agricultural Engineering Building, 1680 Madison Avenue, Wooster, $\mathrm{OH}$ 44691

We appreciate and acknowledge financial support from the Washington State Department of Agriculture Nursery License Surcharge program (Olympia, WA), as well as the donation of cutting material from the University of California, Santa Cruz, Arboretum, and the assistance of the staff at the Arboretum. Thanks are also due to Oregon State University Marion County Master Gardeners for assistance with plot establishment and data collection.

N.B. is the corresponding author. E-mail: neil.bell@ oregonstate.edu.

This is an open access article distributed under the CC BY-NC-ND license (https://creativecommons.org/ licenses/by-nc-nd/4.0/).

https://doi.org/10.21273/HORTTECH04377-19
(Molyneux, 1978). The habit of these shrubs ranges from prostrate and widespreading to upright shrubs and tree forms. Grevillea also display great variations in leaf size and morphology flower color, inflorescence size and presentation, as well as flowering season (Growns et al., 2013), making them popular and commercially successful ornamental plants in regions with a suitable climate.

Grevillea use as a commercial ornamental plant in North America is limited, principally because of a lack of cold hardiness. Almost all of Australia corresponds to the U.S. Department of Agriculture (USDA) hardiness zone 9 or higher (Dawson, 1991), and as a result, only the warmest regions of North America are suitable for outdoor cultivation of any species or hybrid. For landscape use, plants are almost entirely limited to warmer regions of California, Hawaii, and parts of the southeastern United States. Some of the most cold-hardy species or cultivars, most commonly royal grevillea $(G$. victoriae), are also cultivated to a limited extent in western
Oregon and Washington, as well as in southwestern British Columbia.

Much of the information regarding the cold hardiness of grevillea is anecdotal. No comprehensive study of hardiness of the many cultivars or hybrids has been performed. Studies have assessed cold hardiness of individual hybrids like $G$. xgaudichandii (Stanley and Warrington, 1988) or compared the hardiness of a limited numbers of species (Mancuso et al., 2004), including field-grown grevillea being used for cut flowers (Heuer and Markovitz, 2011).

This study was performed to assess the suitability of cultivars and species of grevillea for landscape use in the Pacific Northwest United States USDA hardiness zones 8 a ( 10 to $\left.15^{\circ} \mathrm{F}\right)$ through $9 \mathrm{a}\left(20\right.$ to $\left.25^{\circ} \mathrm{F}\right)$.

\section{Materials and methods}

A total of 85 species and cultivars of grevillea were collected, primarily from the Arboretum at the University of California, Santa Cruz, and three nursery sources in 2010. Cuttings were collected in June, with the exception of royal grevillea (variegated), which was rooted in Dec. 2010 . Tip cuttings $\approx 4$ to 6 inches long were collected; however, the length was dependent on the vigor and size of individual accessions. Cuttings were placed in individual bags according to their accession and refrigerated. Cuttings were processed and stuck at Oregon State University North Willamette Research and Extension Center (NWREC) in Aurora within $3 \mathrm{~d}$. Cuttings were quick-dipped in $2500 \mathrm{ppm}$ indole-3-butyric acid and $1250 \mathrm{ppm}$ l-napthalenaecetic acid (Dip'N Grow, Clackamas, OR) and stuck in 38-cell groove tube trays (T.O. Plastics, Clearwater, MN) in a $2: 1(\mathrm{v} / \mathrm{v})$ mix of horticultural grade perlite and fine milled sphagnum peat. Trays were placed in a mist bed with bottom heat $\left(\approx 21{ }^{\circ} \mathrm{C}\right)$ in a temperaturecontrolled greenhouse $\left(20^{\circ} \mathrm{C}\right)$.

Rooted cuttings were transplanted to 6-inch square nursery pots in Nov.

\begin{tabular}{llll}
\hline $\begin{array}{l}\text { Units } \\
\text { To convert U.S. to SI, } \\
\text { multiply by }\end{array}$ & U.S. unit & SI unit & $\begin{array}{l}\text { To convert SI to U.S., } \\
\text { multiply by }\end{array}$ \\
\hline 0.4047 & $\mathrm{acre}(\mathrm{s})$ & $\mathrm{ha}$ & 2.4711 \\
0.3048 & $\mathrm{ft}$ & $\mathrm{m}$ & 3.2808 \\
2.54 & $\mathrm{inch}(\mathrm{es})$ & $\mathrm{cm}$ & 0.3937 \\
28.3495 & $\mathrm{oz}$ & $\mathrm{g}$ & 0.0353 \\
1 & $\mathrm{ppm}$ & $\mathrm{mg} \cdot \mathrm{L}^{-1}$ & 1 \\
$\left({ }^{\circ} \mathrm{F}-32\right) \div 1.8$ & ${ }^{\circ} \mathrm{F}$ & ${ }^{\circ} \mathrm{C}$ & $\left({ }^{\circ} \mathrm{C} \times 1.8\right)+32$
\end{tabular}


2010 and topdressed with $5 \mathrm{~g}$ of $19 \mathrm{~N}-$ 0P-15.8K controlled-release fertilizer (Florikote; Florikan, Sarasota, FL). The exception was royal grevillea (variegated), which was transplanted in Apr. 2011, and potted with the same protocol. Plants were grown in an unheated retractable roof greenhouse (Cravo, Brantford, ON) until planting in the field site for evaluation. Despite the difference in the collection time of royal grevillea (variegated), the long period of growth during Summer 2011 resulted in a robust liner equivalent to earlier accessions for field planting. A total of 57 grevillea were available in sufficient numbers for the evaluation by the time of planting because not all collected accessions rooted or rooted in sufficient numbers.

The site at NWREC (lat. $45^{\circ} 16^{\prime} \mathrm{N}$, long. $122^{\circ} 45^{\prime} \mathrm{W}, 47 \mathrm{~m}$ elevation) is located in USDA hardiness zone $8 \mathrm{~b}$ ( 15 to $20^{\circ} \mathrm{F}$ ). The planting site was limited by a 0.2 -acre parcel in Latourell loam soil. The limited plot size resulted in the authors choosing to evaluate the maximum number of species and cultivars instead of minimally increasing power through greater replication. Before planting, the site was lightly cultivated by disking to break-up surface compaction in the top few centimeters. Four plant replicates from each accession chosen for uniformity of size, rooting, vigor, and health were planted on 19 Aug. 2011 in rows $350 \mathrm{ft}$ long, oriented north to south, and spaced $12 \mathrm{ft}$ apart with an in-row spacing of $5 \mathrm{ft}$ in a completely randomized design. The planting date was chosen to maximize plant establishment before the drought period the following summer. Although they worked with deciduous trees, it was noted by Richardson-Calfee and Harris (2005) that fall appears to be the best time to plant in landscapes that are not well irrigated.

After planting, grevillea were hand-watered and then overheadirrigated as needed until reliable fall rains occurred in mid-Oct. 2011. Water was not applied to the plants beyond natural rainfall for the remainder of the trial. Fertilizer was not applied at planting or thereafter, and plants were not pruned. Weed control was maintained through biannual application of the pre-emergent herbicides isoxaben (Gallery 75; Dow Chemical Co., Indianapolis, IN) and oryzalin (Surflan A.S.; United Phosphorus, King of Prussia, PA), postemergent herbicide glyphosate (Roundup; Bayer, Leverkusen, Germany), and hand-hoeing. Plants were not sprayed with fungicide or insecticide, and no significant disease or pest issues were observed. Weather data for the evaluation were provided by a Bureau of Reclamation Agrimet weather station at NWREC (U.S. Bureau of Reclamation, 2019), which is located $200 \mathrm{ft}$ from the west edge of the planting (Fig. 1).

Cold injury data were collected on 12 Mar. 2012 and again on 17 Jan. 2014. Plants were visually evaluated for damage using a scale from 1 to 6 as follows: 1 = no injury; 2 = minor leaf injury; $3=$ leaf/stem damage on outer $30 \% ; 4=$ leaf $/$ stem injury on outer $60 \% ; 5=$ killed to ground, recovery evident; and $6=$ dead. Data were analyzed with an analysis of variance (ANOVA) using SAS (version 9.4;

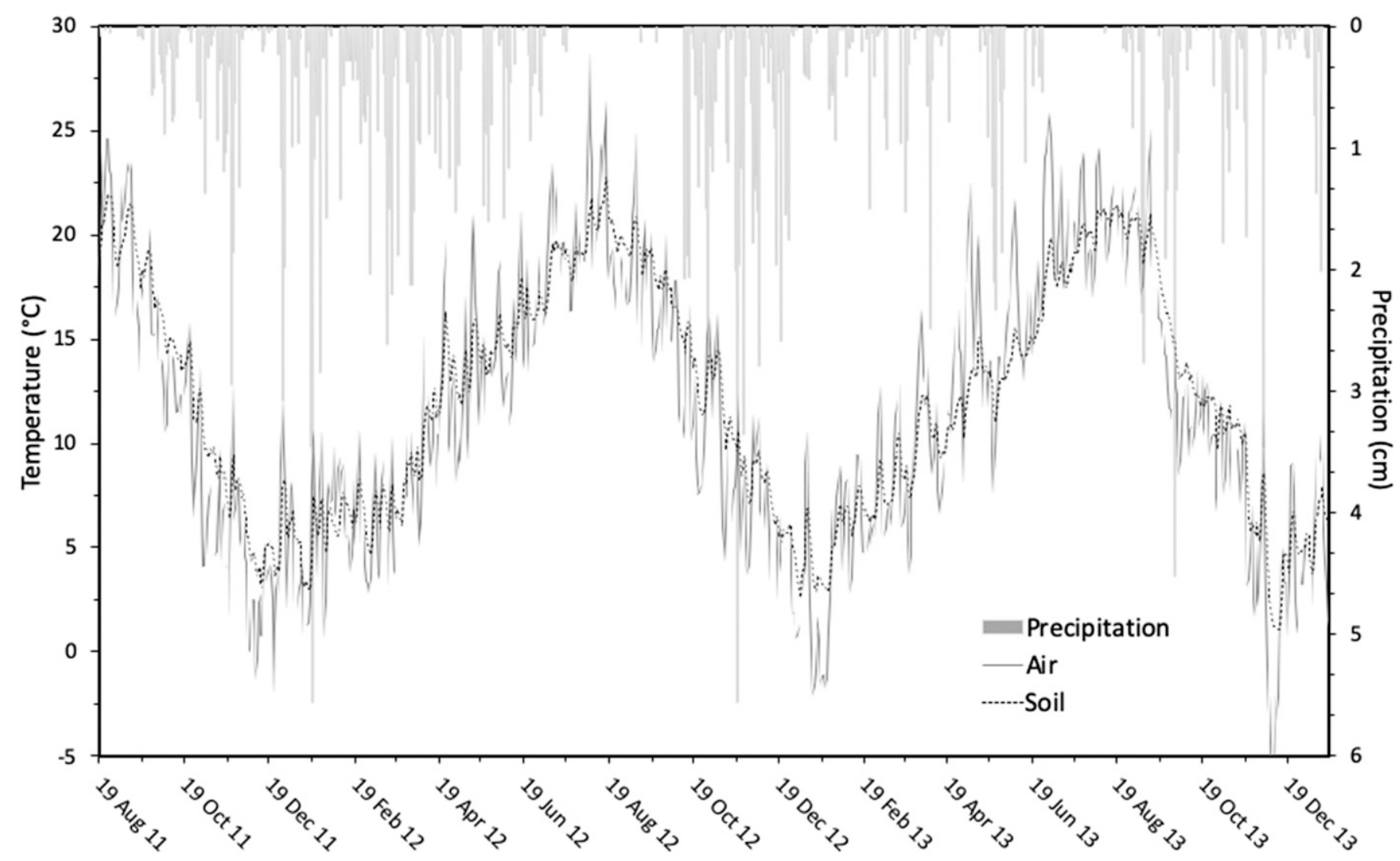

Fig. 1. Daily precipitation and mean air and soil $[(5 \mathrm{~cm}+20 \mathrm{~cm}$ depth $) \div 2]$ temperatures reported by the Agrimet weather station at the North Willamette Research and Extension Center in Aurora, OR, for the duration of the grevillea evaluations: $\left(1.8 \times{ }^{\circ} \mathrm{C}\right)+32={ }^{\circ} \mathrm{F} ; 1 \mathrm{~cm}=0.3937$ inch. 
Table 1. Winter cold injury to grevillea grown during a landscape evaluation in Aurora, OR.

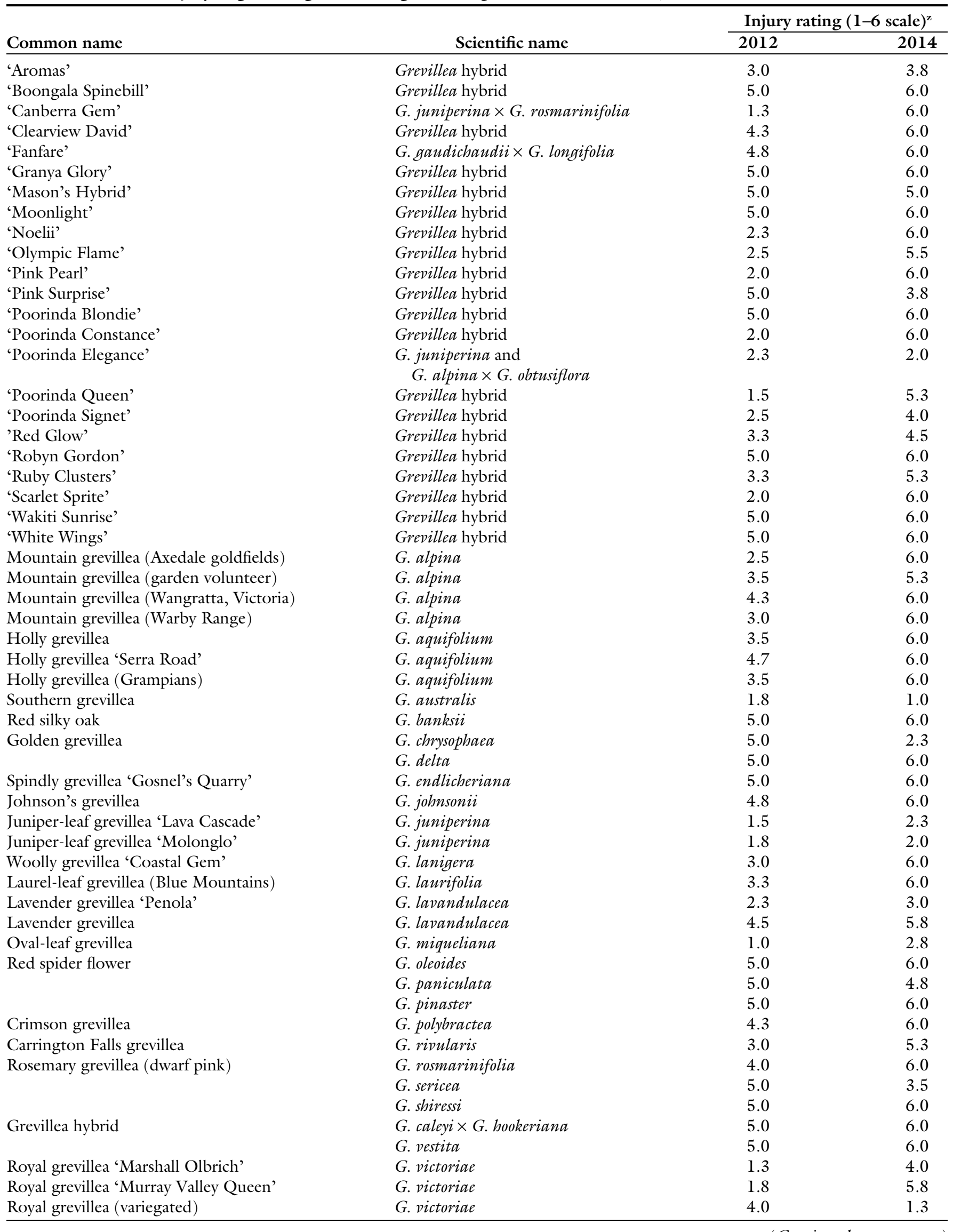


Table 1. (Continued) Winter cold injury to grevillea grown during a landscape evaluation in Aurora, OR.

\begin{tabular}{|c|c|c|c|}
\hline \multirow[b]{2}{*}{ Common name } & \multirow[b]{2}{*}{ Scientific name } & \multicolumn{2}{|c|}{ Injury rating $(1-6 \text { scale })^{\mathrm{z}}$} \\
\hline & & 2012 & 2014 \\
\hline $\begin{array}{l}\text { G. ×gandichaudii } \\
\text { Statistics }\end{array}$ & G. acanthifolia $\times$ G. laurifolia & 2.8 & 5.5 \\
\hline Tukey's HSD & & 1.7 & 2.4 \\
\hline$P$ value & & $<0.0001$ & $<0.0001$ \\
\hline
\end{tabular}
dead. The 2012 rating was conducted on 12 Mar. 2012; the 2014 rating was conducted on 17 Jan. 2014.

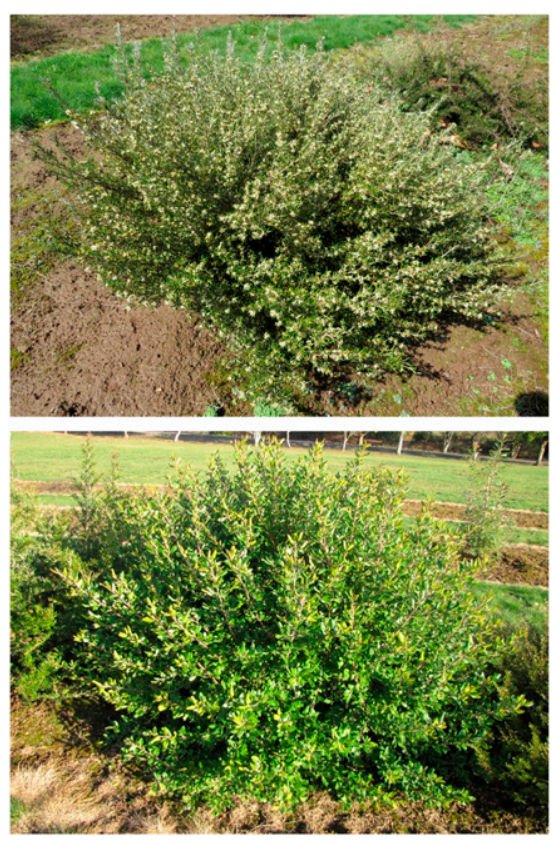

Fig. 2. Some images of grevillea best suited for Pacific Northwest United States landscapes: southern grevillea (top) and oval-leaf grevillea (bottom).

SAS Institute, Cary, NC) and means were separated when appropriate using Tukey's honestly significant difference test ( $\alpha=0.05$ ) to compare the injury ratings of individual accessions.

\section{Results and discussion}

Weather in Fall 2011 was mild and allowed for the successful establishment of all plants. Between 1 Nov. 2011 and 1 Apr. 2012, minimum temperatures dropped below freezing on 36 occasions. The coldest temperatures, -4.4 and $-3.3{ }^{\circ} \mathrm{C}$, were recorded on 13 and 22 Dec., respectively (Fig. 1). Winter 2012-13 was similarly cold, with minimum temperatures below freezing on 27 occasions during the period from 11 to 23 Jan. The lowest temperatures were near $-4.5{ }^{\circ} \mathrm{C}$, which occurred on four occasions, 2 Jan., 12 Jan., 21 Jan., and 22 Jan.
2013. Winter 2013-14 featured an extended cold spell that began on 4 Dec., with a low temperature of $-3.8{ }^{\circ} \mathrm{C}$ (Fig. 1). From that date through 12 Dec., minimum temperatures were below freezing, culminating in low temperatures of -13.3 and $-11.7^{\circ} \mathrm{C}$ on the nights of 8 and 9 Dec., respectively.

Although the temperatures observed in 2011-12 were milder than those of a typical zone $8 \mathrm{~b}$ winter, this was enough to cause considerable foliage or stem damage to many accessions. Freeze-damaged grevillea foliage typically turns brown or black, and the most heavily damaged plants suffered foliage damage to the entire canopy (Table 1). Similar conditions in 2012-13 produced insufficient symptoms to warrant an evaluation. Whether this was the result of greater hardiness because the plants were older is unclear, although studies have demonstrated increasing hardiness with the increasing age of tissue in woody plants (McNamara and Pellett, 2000). The cold temperatures experienced in Winter 2013-14 exceeded the tolerance of most of the accessions and caused major damage throughout the evaluation (Table 1 ).

The level of injury to most of the accessions in the evaluation, especially following the cold weather of Dec. 2013 , was not surprising because the majority of the accessions are native to low-elevation areas of Western Australia, New South Wales, and Victoria, which correspond to USDA hardiness zone 9. Injury to specific cultivars varied between the two cold spells evaluated in this study; in some cases, they varied considerably. This was seen to some extent in previous landscape studies of woody plants (Bell, 2009; Bell and Altland 2010). Although there is considerable literature about the variations in the cold hardiness of woody plants between seasons within a given year, no work has addressed the causes of variation in hardiness of individual plants between growing seasons. The severity of the cold weather and its duration, as well as the time of onset and physiological status of the plant, presumably influence the level of damage.

From the standpoint of landscape use, a plant that had an injury rating exceeding 2.5 during either winter would probably be unsuitable for landscape use in western Oregon. In $2011,68 \%$ of accessions did not meet this threshold of cold hardiness (32\% did). In $2014,89 \%$ of accessions did not meet the threshold (11\% did). Among the least damaged plants during these cold events were cultivars and selections of juniper-leaf grevillea, oval-leaf grevillea, and southern grevillea. The last two of these are commonly found at higher elevations in Australia. Oval-leaf grevillea grows in high-altitude forests in eastern Victoria, where it forms a large shrub up to $8 \mathrm{ft}$ tall (Makinson, 2000) (Fig. 2). During our evaluation, it formed a robust, rounded shrub that was $5 \mathrm{ft}$ tall by 2014 , and it begun producing red flowers in late winter. Southern grevillea, sometimes also referred to as alpine grevillea, is found in alpine to subalpine altitudes in the mountains of southeastern Australia, and it is widely distributed in Tasmania (Makinson, 2000) (Fig. 2). During this evaluation, southern grevillea grew into a rounded shrub that was $2.5 \mathrm{ft}$ tall and $2.5 \mathrm{ft}$ wide by 2014 , and it freely produced fragrant white flowers in April.

Two cultivars of juniper-leaf grevillea also displayed relative hardiness. 'Molonglo' and 'Lava Cascade' form prostrate, wide-spreading, fairly dense groundcovers up to $1.5 \mathrm{ft}$ tall that have apricot and red flowers, respectively. 'Molonglo' was developed in the early 1960s at the Australian National University, and it established a reputation for high frost tolerance in the 
landscapes of the Canberra region (Australian Cultivar Registration Authority, 1974). In this evaluation, it displayed only minor leaf damage during the Dec. 2011 and Dec. 2013 freezes. 'Lava Cascade', also marketed as 'Low Red', is a groundcover selection of uncertain origin that displays hardiness comparable to 'Molonglo'.

Another accession that displayed good hardiness was 'Poorinda Elegance'. This cultivar is a hybrid of a juniper-leaf grevillea of New South Wales origin and another hybrid of mountain grevillea ( $G$. alpina) and obtuse-leaf grevillea ( $G$. obtusifolia); it forms a rounded, spreading shrub up to $6 \mathrm{ft}$ tall with yellow flowers (Tully, 1977). The various accessions of mountain grevillea did not exhibit noticeable cold tolerance, and obtuse-leaf grevillea is native to coastal Western Australia, where frost is rare. Therefore, the cold hardiness of this hybrid is likely derived from juniper-leaf grevillea.

A surprise during the evaluation was the noticeable injury to the two cultivars of royal grevillea, Murray Valley Queen and Marshall Olbrich. The species now consists of three subspecies, two of which are $G$. victoriaessp. victoriae and G. victoriae ssp. nivalis. The former is endemic to high montane forest in Victoria, and the latter is endemic to high montane forest in New South Wales. Because of its origins and record of cultivation in the Pacific Northwest United States, this species was expected to be one of the hardiest in the evaluation. However, the array of cultivars observed in landscapes are not easy to distinguish, and landscape specimens have exhibited injury in severe winters. 'Murray Valley Queen' is considered to be a selection of $G$. victoriae ssp. nivalis (Olde, 2007). 'Marshall Olbrich' is of undocumented origin, but it apparently arose as a seedling at Western Hills Nursery in Occidental, CA. Despite the demonstrated cold injury, the showy winter blooms of this species make it a desirable landscape plant for places where it can survive.

The grevillea that exhibited the least cold damage and the most promise for landscape use in the Pacific Northwestern United States were 'Poorinda Elegance', southern grevillea, cultivars of juniper-leaf grevillea including Lava Cascade and Molonglo, and oval-leaf grevillea.

\section{Literature cited}

Australian Cultivar Registration Authority. 1974. Grevillea juniperina 'Molonglo'. 16 Apr. 2017. <https://www.anbg.gov. au/acra/descriptions/acc002.html>.

Bell, N. 2009. Evaluation of growth, flowering, and cold hardiness of ceanothus in western Oregon. HortTechnology 19:411-417.

Bell, N. and J. Altland. 2010. Growth, flowering, and cold hardiness of rockrose in western Oregon. HortTechnology 20: 652-659.

Dawson, I. 1991. Plant hardiness zones for Australia. Austral. Hort. 90:37-39.

Growns, D.J., A.M. Crowhurst, P. Umeritiya, and M. Webb. 2013. Breeding and development of new hybrids in Grevillea R. Br. Ex Knight. Acta Hort. 1000:519-525.
Heuer, B. and T. Markovitz. 2011. Interactive effects of frost and effluent irrigation on Grevillea species. Isr. J. Plant Sci. 59:197-206.

McNamara, S. and H. Pellett. 2000. Cold hardiness of Phellodendron sachalinense Friedr. Schmidt seedlings increases with age. HortScience 35:304-305.

Makinson, R.O. 2000. Grevillea, p. 20450. In: A. Wilson (ed.). Flora of Australia. Volume 17A. Proteaceae 2. Austral. Biol. Resources Study, Canberra, Australia.

Mancuso, S., F.P. Nicese, E. Masi, and E. Azzarello. 2004. Comparing fractal analysis, electrical impedance and electrolyte leakage for the assessment of cold tolerance in Callistemon and Grevillea spp. J. Hort. Sci. Biotechnol. 79:627-632.

Molyneux, W. 1978. Grevillea in horticulture. Austral. Plants 75:287-298.

Olde, P. 2007. The Grevillea victoriae complex-New species in the flora. Grevillea Study Group Nwsl. 77. Assn. Soc. Growing Australian Plants, Ulverstone, Australia.

Richardson-Calfee, L. and J.R. Harris. 2005. A review of the effects of transplant timing on landscape establishment of fieldgrown deciduous trees in temperate climates. Hort Technology 15:132-135.

Stanley, C.J. and I. Warrington. 1988. Seasonal frost tolerance of some ornamental evergreen broad-leaved and coniferous tree and shrub species. N. Z. J. Expt. Agr. 16:239-248.

Tully, P. 1977. The Poorinda grevilleas. Austral. Plants 9:213-215.

U.S. Bureau of Reclamation. 2019. Agimet. 7 Oct. 2019. <https://www.usbr. gov $/ \mathrm{pn} /$ agrimet $/>$. 